\title{
Corporate Board and Firm Risk: An Emerging Market Perspective
}

\author{
M. Farwis ${ }^{1}$, M. C. A. $\operatorname{Nazar}^{2}$ \& A. A. Azeez ${ }^{3}$ \\ ${ }^{1}$ Department of Accountancy, Sri Lanka Institute of Advanced Technological Education, Sammanthurai, Sri Lanka \\ ${ }^{2}$ Department of Accountancy and Finance, Faculty of Management and Commerce, South Eastern University of Sri \\ Lanka, Sri Lanka \\ ${ }^{3}$ Department of Finance, Faculty of Management and Finance, University of Colombo, Sri Lanka \\ Correspondence: Mahrool Farwis, Department of Accountancy, Sri Lanka Institute of Advanced Technological \\ Education, Sammanthurai, Sri Lanka. Tel: 94-77-636-7585. E-mail: farwism@gmail.com, farwis@ sliate.ac.lk
}

Received: July 30, 2020

doi:10.5430/ijfr.v11n6p301
Accepted: September 14, 2020

Online Published: December 15, 2020

URL: https://doi.org/10.5430/ijfr.v11n6p301

\begin{abstract}
This study examines the relationship between board features and firm risk of listed companies in Colombo Stock Exchange for the period of 2010 to 2017. This research was carried out based on positivistic paradigm with the quantitative methodology. Secondary data were collected and analyzed using panel data analyze techniques to obtain quantitative measures of descriptive statistics, correlations, and regression analyses. The results show that the board features variables such as Board size, Women on board, Non-executive director, CEO Duality and Director Interlock have significant impact on firm risk. The results are consistent with agency theory perspective. On the other hand, Audit committee does not show any impact on firm risk in Sri Lankan companies. Our findings reveal that consistence is with theoretical expectation and code best practices. Further, it suggests that as far as the risk is concerned the existing corporate governance practices and code of best practices are effective in Sri Lankan context.
\end{abstract}

Keywords: corporate governance, board features, firm risk, emerging market

\section{Introduction}

Major corporate collapses worldwide and the global financial crisis brought considerable attention on risk management and necessity of controlling risk (Sorensen and Miller, 2017). As per Jensen and Meckling (1976) corporate governance (CG) measures like board structure, compensation structure and ownership structure determines the risk of the firm. Hence, CG systems are trusted to be effective as an instrument for monitoring and control to prevent irregularities (Hossain, 2020). Board of directors are the supreme body to involve in the risk oversight and internal control to safeguard the major and minor shareholder's interest (Davis, 1997). The board of directors not only advise and monitor management but also participate in strategic decisions which have inherent risk involved. This contribution could be served through competence level of the board configuration. The board's mismanagement of fund and less risk management oversight were the main reasons for Sri Lankan corporate scandals took place like Pramuka Bank, Vanik incorporation, Lanka Marine Service Ltd and Golden Key (Senaratna \& Gunaratna, 2009; Rajeevan \& Ajward, 2019). As per the above evidences, it is clear that the effectiveness of corporate boards of public companies is subjected to debate in Sri Lanka. In addition to that, the appointment of directors' is influenced by major shareholders because of concentrated ownership prevailing (Mapitiya et al., 2015; Farwis \& Azeez) where the code of best practice also does not even concern about the board's attributes.

Moreover, corporate governance (CG) best practices and compliance level significantly vary in developed and emerging economies due to contextual and economic differences (Mishra, 2019). Hence, studies result based on those economies are invalid in application to the emerging economies. Therefore, the objective of this paper is to explore the knowledge about how board features (board size, board independence (NED), chairman/CEO duality, women proportion in the board, director interlocking and audit committee independence) influence on firm's risk. This study will guide regulators, policy makers and corporate management by providing empirical evidence on board features and their significance role in determine risk of corporate companies in Sri Lankan context. The results depict that the smaller in board size with women proportion and adequate non-executive directors with CEO Duality, holding multiple directorship seems to be significantly influenced on firm risk. These findings are consistent with agency theory perspective, but on the other hand Audit committee does not show any impact on firm risk. The finding 
of the empirical study reveals that consistence is with theoretical expectation and code best practices.

This paper contributes CG and risk literature, by viewing that board characteristics associate with risk of firms in Sri Lankan perspective. This paper comprises four sections. Section 2 provides a review of the literature on risk and presents the hypotheses. Section 3 describes the sample and empirical methods. The empirical results are presented in Section 4. Final section concludes the paper.

\section{Literature Review and Hypotheses Development}

Primary responsibility of the board is to look after the interests of shareholders (Jenson \& Meckling, 1976). Particularly, the board needs to be on alert for any conflict that may arise between the interests of management in boosting returns while assuming risks, and the interests of the company's longer-term stakeholders (Kyei, 2019). This kind of conflict of interest is often referred as an "agency risk." This is the reason to draw a line between corporate governance and risk management (RM). In this context, understanding of RM is essential. RM is not considered to be the technique for gradual reduction of firm's risk whereas, how organizations identify and perceived them according to the risk appetite level (Crouhy et al., 2014). Further, they argued that "RM and risk-taking are mere concept like two sides of the same coin" firm who are striking balance between these two phenomena, is highly likely to get more reward and high performance.

Stiles and Taylor (2002) state that, directors of the board (BOD) have vested important roles for firm risk taking which are strategic role, monitoring role and institutional role. These roles help BODs for formulating the way for the firm in align with stakeholders' interest, monitor operation of mangers of the firm to safe the shareholder's interest and BODs have legislative and fiduciary obligation towards shareholders. These roles influence the BODs for risk taking and risk management. The board characteristics like board size, gender diversity, CEO duality and non-executive directors which influence the BOD's strategic role and monitoring role (Sudha et al., 2018). As per the literature review the following hypothesis are assumed for this study.

\subsection{Board Size and Firm Risk}

The crucial role of the BOD is to observe the day to day operation of managers of the firm and BOD is responsible for decision making (Sudha et al., 2016). The size of the board represents extent of experience, knowledge and expertise based on the numbers in the board (Chaganti, Mahajan, \& Sharma, 1985). The association between board size and the variability of corporate performance potentially arise because larger boards have the communicationcoordination problems and the agency problems (Cheng, 2008), however, Jensen (1993) argues that when board consists more members, then agency problem is unavoidable due to over influence and control of CEO and further finds that CEO dominant increase along with board size increase. Simultaneously, when board size increases seven or more then, BOD's function become inefficient, this context gives CEO to take upper hand in risk management (Jensen, 1993).

On the other hand, Yermack (1996) contents that huge number in board can delegate monitoring function to BODs for effective representation on behalf of shareholder. Accordingly, size of the board affects the firm risk directly and several explanations were presented by many researchers. In the large firm, information sharing and synchronization of BOD can become challenge which gives path the CEO to complementariness, in doing so efficiency for risk mitigation of the board will be reduced (Jewell \& Reitz, 1981; O’Reilly et al., 1989; Goodstein \& Boeker, 1991; Lipton \& Lorsch, 1992; Jensen, 1993) on the top of that finding shows large board can provide proficiency for sound risk management (Pfeffer, 1972; Dalton, Daily, Ellstrand, \& Johnson, 1998).

According to Moscovici and Zavalloni (1969) and Kogan and Wallach (1964), the size of the decision-making group negatively associated with firm risk. In line with this finding, in large board, decision making for riskier project become very difficult because of attaining agreement among groups (Sah \& Stiglitz, 1986). Consistent with this idea, Cheng (2008) finds that US firms with larger boards are associated with lower performance volatility. Nguyen (2012) shows with Japanese firm that large board consisting different profiles directors turn over high, thus greater uniformity in managerial profiles and greater conformity in displayed behaviours which neglect the individualism and proms to unite decision which encourage the risk taking. As Cheng (2008) reported that negative relation between board size and firm risk with the USA sample and Pathan (2009) too shows substantial inverse relation between size of board and risk of firm as same as the US sample of companies. And also, Sudha et al (2016) exhibits that negative relation with board size and firm risk using UK sample. However, no studies perform to show the relation between board size and firm risk using Sri Lankan sample. Due to non-availability of theories regarding the relation researcher assume the relation based on the existing literature support. The existing studies supports an inverse relation between board size and the firm risk. Therefore, to test the association in Sri Lankan companies' 
corporate board this hypothesis is developed as follows.

H1: Size of Board has inverse association with risk of listed companies in Sri Lanka.

\subsection{Non-executives Directors (NED) and Firm Risk}

A board must comprise of executive and non-executive directors. In a healthy board more than half of the members to be NED except chairman of the board (Combined Code,2003). Fama and Jensen (1983) state that BODs are the group responsible for safeguard the interest of shareholders and evaluating \& monitoring performance of managers. In the same view, Jensen and Meckling (1976) depict that significant positive association between proportion of NEDs and firm performance through efficient monitoring and control of company operations. According to this perception, shareholders assign much more NEDs to carry out effective monitoring role.

Literature shows multiple findings such as no any association, positive association and negative relation among NED and Risk. Chaganti et al. (1985) finds that no any significant relation between NEDs and risk among matched US companies. The same result shows by Cheng (2008) with US corporation. In line with this finding, Sudha et al., (2016) did a study of UK sample of 260 large companies with the period of 2005 to 2010 . The results find that the amount of NEDs on board helps to diminish risk of firms whereas it indicates weak relation. This finding demands further exploration, hence UK firms by average consist more than half of the directors are NEDs.

On the other hand, contrast to the above finding, US studies with bank holding samples show NEDs in the board positively related with risk taking (Pathan, 2009). Consistent with this study, another Australian sample literature shows, more NEDs in the board produces positive performance with lesser equity risk (Christy et al., 2013). As far as NED concern with the firm risk some studies find no significant relations with firm risk (Chaganti et al.,1985), however, one line of study finds positive relation between NEDs and firm risk (Pathan, 2009). Although, past studies show mixed finding with NEDs and risk-taking, agency theory assuming that negative significant relation between NEDs and risk. According to the theoretical stand, the hypothesis proposed to test in the Sri Lankan context.

\section{H2: The NEDs is negatively related to risk of listed companies in Sri Lanka}

\subsection{CEO Duality and Firm Risk}

$\mathrm{CEO}$ is the main position in a corporate firm and he/she is responsible for overall management of the firm. Therefore, powerful CEOs can consistently influence key decision in their firms, in spite of potential opposition from other executives. The role duality happens when a person simultaneously holds the position of CEO and board chairman. The Combine Code (2003) recommends that there should be a clear division of responsibilities between CEO and board chairman. Agency theory supports that separation between management and control for effective oversight of the board (Jensen \& Mackling, 1976). Further they content agency theory assumes that CEOs with dual power, leading CEO to make major decision with the self-interest. Due to impartial behaviour, high risk decision will be averted and choices will not be deemed with risk (Fama \& Jensen, 1983).

With this theoretical view point, many researchers argue that CEOs will be any risk neutral or risk averse and mangers are not really risk seekers if he/she is with duality role (Wiseman \& Gomez-Mejia, 1996; Carpenter et al., 2003; Sanders \& Hambrick, 2007). This result is confirmed by (Adams et al., 2010) that CEO with duality role uses authority for own interest. In this study, Adams et al (2010) emphase on the power amid the top managers and CEOs. Meantime, many earlier researches suggest that CEOs with duality have less performance. For instance, Amihud and Lev (1981) finds that powerful CEOs have encouragement to involve in risk reduction actions. On the other hand, stewardship theory is suggesting to have a single person with dual responsibility, because it could overcome contradictory opinions and eradicate vagueness on who is accountable for decisions making. According to theoretical stand, few studies have stated that firm depends on CEO's duality role is favourable to the firm. Theoretical views are contracting each other in terms of CEO duality, however, some empirical evidences show interesting in finding with firm risk.

Pathan (2009) finds that CEOs with duality position are involving risk reduction events. This research results stated that CEO's earning is connected with organizations' performance, through this CEOs are entitle to high bonuses, equity options and profit-sharing system. Alternatively, insolvency or low performance of the firm could lead to lose of jobs. Therefore, higher executive carefully selects low risky project in order to overcome employment risk. And also, costs of bankruptcy can contribute to managers in levered firms to select less risky projects (Parrino, Poteshman, $\&$ Weisbach, 2005). Therefore, a powerful CEO may prefer to take less risk.

Nevertheless, another line of study shows contradicting result where CEO duality is related with extreme firm risk. CEOs are eagerly facing and hoping higher bottom results by using high power, the result shows powerful CEO are 
related with higher firm risk (Adams et al., 2005). Another strand of the study shows the similar finding. Lewellyn and Muller-Kahle (2012) prove with USA samples and Sudha et al (2016) shows with UK sample that CEO duality is significantly associated with firm risk taking. Based on the above arguments and theoretical concern, it can be hypothesized that CEO duality is positively associated with firm risk. From this perspective and the agency theory assumption, this could be hypothesized as:

\section{H3: CEO duality is positively associated with firm risk of listed companies in Sri Lanka.}

\subsection{Women Proportion on Board and Risk of Firm}

The worldwide concerns surrounding excessive risk-taking and governance issues, in the wake of the recent economic crisis, has focused on further reform to create balance and diversity on decision-making bodies in the public and private sectors (Wilson \& Altanlar, 2009). Recent academic studies have sought to establish the linkages between board level diversity, including female representation aspects of corporate performance and governance (Adams \& Ferreira, 2009). Most of the corporate boards are occupied with women according to the demographical changes and women proportion increase in the population. Not only by population wise, but also women are with the increase potential of education and network (Sudha et al., 2016).

Gender diversity in corporate board is a matter, hence effective board should comprise gender-balance board. This board operates high effective due to better understanding of stakeholders, sharing new ideas and diversity consist wide-ranging experience (Davies, 2011). With this view, many countries take initiatives to legally admit the women representation. Some examples are; France and Norway legally force that forty percentage of board should be occupied by female. In Belgium and Netherlands, thirty percent of board is filled by women. Meantime, European Parliament legally made resolution for forty percent NED to be occupied by female members. In UK, Lord Davies on the approach to increase representation of women on FTSE 100 boards to at least 25\% by 2015(www.gov.uk), but in Sri Lanka no such provision on women representation is mandate.

Existing literature mostly shows the evidence for gender mix helps for well governance. Females are very sensitive and extreme in their Non-Executive directors' positions and diligently attending meetings (Izraeli, 2000; Huse \& Solberg, 2006). Further, women are regularly attending meetings compared with men, which enables them for controlling and monitoring the management (Adams \& Ferreira ,2009). This sincerity in meeting attendance helps women to participate in performance evaluation of the board and contribute to better monitoring and controlling of day today activity. Studies show gender mix lead to tougher monitoring which resulted lower performance (Adams \& Ferreira, 2005). Risk related researcher's point of view the possibility that women are more 'risk-aware' than 'risk-averse' and are more thorough and realistic in the management of risk. Adams and Ferreira (2008) find that women directors are more likely to be involved in monitoring-related committees and are more likely to attend meetings. Adams et al (2005) find that "female and male directors differ systematically in their core values and risk attitudes". An experimental study evidence that women are less risk-seeking in financial decision making (Powell \& Ansic, 1997). And, another study is also stronger in this argument that in terms of risk attitudes women are more risk averse than men (Croson \& Gneezy, 2009).

Literatures in the discipline of decision-making noted that the women attitude in investment decision-making women are risk-averse compared with the counterpart (Jianakoplos \& Bernasek, 1998). Another UK study proves this state empirically in which female in the board negatively associated to firm risk (Sudha et.al,2016). Some literatures show controversial finding that, women are risk-seeker and influencing risk positively. They consent that women on board do not always like for risk-avers decision making. To validate this arguments, Berger et al (2012) shows significant positive association between women representation and firm risk. So as to hypothesize, most risk relevant studies support the view of gender proportion on board lead to better control and monitoring of the management. The agency theory frame work too supports the benefits of female representation on boards (Benkraiem, Hamrouni, Lakhal \& Toumi, 2017). Accordingly, gender diversity reduces conflicts of interest between managers and shareholders. It is then considered to be a good corporate governance device related to board composition. Therefore, this is an experiment purpose to incorporate the women in this study to find the association in Sri Lanka and hypothesized as follows:

H4: The proportion women on the board is inversely associated to firm risk of listed companies in Sri Lanka.

\subsection{Audit Committee Independence and Firm Risk}

The Cadbury report (1992) suggested to appoint an audit committee by the board for monitoring and control of the management for effective risk management. This committee is responsible for formulating strategies for risk management, evaluating risk management activities and finally assessing financial report (COSO, 2004). Therefore, 
this committee is the apex body of risk assessment and risk appetite. Audit committee is responsible for recommending the selection of external auditors to the full board; ensuring the soundness and quality of internal accounting and control practices; and monitoring external auditor independence from senior management.

Agency theory assumed significant positive association among financial statements quality and audit committee (Beasley, 1996; Felo, Krishnamurthy \& Solieri, 2003). Further, agency theory advanced that audit committee's independent members can help in monitoring management actions and reduced information asymmetry towards shareholder (Beasley, 1996). According to Harrison (1987), risk management committee which is under audit committee, facilitates to improve corporate accountability through autonomous monitoring of firm's activities, so that corporate legitimacy will be enhanced. The audit committee members consider apex team in order to make sure shareholder's interest protected through oversight and managing financial statement process (Munro \& Buckby, 2008; Baxter \& Cotter, 2009). This view was proved by (Klein, 2002b), audit committee effectiveness mainly depends on having more independent members which enable overall corporate governance success. This could further explain with the Signaling theory perspective. Signaling theory mainly deals with information asymmetry in the market and commonly assists to discourse information asymmetry issues. When an independent audit committee discloses the information about the risk management practices these would give favourable signal to the market, which enhances the firm performance and reduces the firm risk (Subramaniam et al., 2009).

Past studies show the association in between audit committee and performanc. A study reveals that firm recorded high performance with higher number of autonomous members in the audit committee (Saat, Karbhari, Xiao, \& Heravi, 2012). The same result is depicted by (Chan and Li ,2008; Aggarwal et al., 2009). Erickson et al. (2005) finds a positive association between independence audit committee and performance. In contrast, some studies show different findings for instance, Saat et al. (2012) did not report any association among audit committee and firm performance. Erickson et al (2005) shows a positive association among audit committee and firm value. In risk related literature finding the association between audit committee and firm risk as per the researcher knowledge is highly unexplored globally and locally. Based on the theoretical background, NED are the monitoring team of the board and inclusion of them in the audit committee would result the low risk and effective risk management and literature supporting the association between audit committee with firm risk is negative. Hence, the below hypothesis is constructed for empirical testing.,

\section{H5: Audit committee independent is inversely associated to firm risk of listed companies in Sri Lanka.}

\subsection{Director Interlocking and Firm Risk}

Commonly directors are involving simultaneously in many corporate boards which is called "director interlocking" in order to serve their expertise by inputting strategic decision making. Director interlock arises when a director simultaneously is occupied in many boards. Agency theory initiators find out that outside directorship, serve as a vital encouragement for directors to improve their status as monitoring expert (Fama \& Jenson, 1983). Moreover, they reported that multiple directorship is the indicator for an expert director. Then, interlock directors earn excellent experience through multiple seats, it enables for being active monitor to reduce agency cost and enhance shareholder's wealth which ultimately impacts the risk of firm. On the other hand, when directors are having more occupancy they may be too busy; as a result, monitoring function will be ineffective. Due to that, agency cost may increase and shareholders in the position to lose their wealth which in turn increase firm risk (Jamal \& Bhuiyan, 2015).

Available studies in relation to interlocking directorship demonstrate that directors with independent position are good for monitoring management but this is not the case always, because interlocking directors are part of independent directors and they occupy many boards and bearing high responsibility (Keys \& Li, 2005). In contradiction, Mizruchi and Galaskiewicz (1994) report that "if interlocking is a successful method of cooperation, then heavily interlocked firms should be more profitable than less interlocked firms". Nevertheless, research finding on this phenomenon around the globe is uncertain (Mizruchi, 1996). Some literatures find the positive association with firm performance such as Carrington (1981) in Canada, Meeusen and Cuyvers (1985) in Belgium find a clearly positive association with performance and interlocks. Burt (1983) shows marginal positive association and Pennings (1980) reports mixed outcomes. On the other hand, Richardson (1987) in Canada, Lincoln et al. (1996) in Japan and Fligstein and Brantley (1992) in USA show inverse relation. However, through interlock directorship board gets benefit of experience with risk shrinking behaviour of interlock directors (Hunton \& Rose, 2008; Jamal \& Bhuiyan, 2015; Farwis \& Nazar, 2019).

Devos, Prevost and Puthenpurackal (2009) find that poor performing firms are having high interlock and also another study suggests that majority of outside directorship companies have significantly lower the performance (Finch \& 
Shivdasani, 2006). Another finding shows that if there is concentrated ownership in the board structure, it creates possible environment for interlock relationship with firm (Jamal \& Bhuiyan, 2015) and the mean time firm performance might be exaggerated by ownership - control structure which is prevailing in Sri Lanka (Mappitta et al., 2015; Senaratna \& Gunaratna, 2008). Interlocking directorship and the association between firm risk and firm performance have not been done by using Sri Lankan sample. Therefore, it seems to be the pioneer study in this strand of knowledge. Therefore, it could be the hypothesis:

\section{H6: Director Interlocking is inversely associated with firm risk of listed companies in Sri Lanka.}

\section{Methodology}

\subsection{Method and Sample}

This research aims to study the relationship between selected CG variables and firm risk. Quantitative approach is employed (Zang, 2012; Alhadab et al., 2016) adopted same quantitative approach. The population of the study is 293 companies listed in the Colombo Stock Exchange representing twenty industry sectors. In selecting sample, the banking, finance and insurance sector companies were excluded. Due to data unavailability some companies were removed and finally 156 companies were selected. The sample period of the study was eight years from 2010 to 2017. Internal corporate governance variable refers to here as independent variables and It included Board Size, Non-Executive Directors, CEO Duality, Women on board, Audit Committee independence and Director Interlock. The current study ascertains firm risk as endogenous variable and measures it on the basis of market measure, accounting measure and mix of accounting and market measures. Firm risk measures used in this study are total risk (TR), financial risk (FR) and asset return risk (ARR). Firm size, Firm Performance and Leverage were used as control variables.

\subsection{Independent Variables}

Internal corporate governance variable refers to here as independent variables and included Board Size, Non-Executive Directors, CEO Duality, Women on board, Audit Committee independence and Director Interlock. The size of board will be measured as the total number of board members. The independence of the board (NED) will be measured as percentage of independent directors. The research represents dummy variables for board CEO Duality. If one individual holds the role of CEO and the chairman will be coded ' 0 '. If the positions are held by two separate people will be coded ' 1 '. The women participation is measured as proportion of female on the board will be used to represent occurrence of women. Audit committee independence is distinct as the number of independent professional members in the audit committee members. Audit committee will be measured by number of professional NED in the audit committee. Director Interlock will be measured by total percentage of interlocking with the board with other firm's board. It could be measured the proportion of directors on the board with directorships in other companies to the total number of directors on the board of the company.

\subsection{Dependent Variable}

The current study ascertains firm risk as endogenous variable and measures it on the basis of market measure, accounting measure and mix of accounting and market measures. In this examination, researcher uses the two folders of dimension using market and accounting data which makes sure that the finding of the study is vigorous. Firm risk measures used in this study are total risk (TR), financial risk (FR) and asset return risk (ARR). Total Risk (TR) is measured by the standard deviation of the firm's daily stock returns for each fiscal year. It is measured as the standard deviation of the rate of return on equity for the company, and is expressed as a rate of return per month computed from the (continuously compounded) equity rates of return for the company's equity. The standard deviation is a measure of historical volatility, and is used by investors to gauge the amount of expected volatility. This measure encompasses both systematic and unsystematic risk and measured bases on past studies as standard deviation of equity returns for each financial year (Laeven and Levine, 2009; Wright et al., 1996; Hutchinson; 2001; Nguyen, 2011; Pathan, 2009; Sudha et al., 2016).

ARR is considered as a risk measure for the variance of the asset earning. ARR is computed as the standard deviation of the daily stock returns times the ratio of market value of equity to market value of total assets times square-root of the approximate number of trading days in the year which is 250 (Flannery \& Rangan, 2008; Pathan, 2009; Sudha et al., 2016). FR which represents the accounting data used by (Eling \& Malank, 2011). These are the measures generally help to calculate firm risk and past studies on CG and risk used these as measures. To measure FR, logarithm of the ratio of total assets to total shareholder equity is used. Total assets are defined as the sum of current and non-current assets. Total shareholder equity is composed of common equity, minority interest, and preferred equity. 


\subsection{Control Variables}

In this study, there are three variables identified as control variables such as firm size, Firm Performance and Leverage. Firm size helps to control variance in size of the firms. Big firm has many ways to enter to capital market and get fund with good deal (Ferri and Jones, 1979). Due to the accessibility of fund, maintaining leverage is easy which allows firm to invest more money, so it is assumed that big firms are related with low risk. Next control variable is firm performance. Firm performance determines the risk taking of the firm, hence if planned performance did not meet in last year, then top executives are prone to seek high risk to achieve targeted performance. So, it is projected that low performance of the past year will be related with higher firm risk. To eliminate outlier in control variables data winsorized performed at $1 \%$ in each tail.

\subsection{Analytical Strategies and Regression Model}

To attain research aim, descriptive statistics, correlation analysis, ordinary least square regression analysis and panel version of the regression analysis are used. As per Green (2003) panel data analysis is the appropriate data analysis technique for a study of secondary data nature as it consists both cross-sectional and time-series data. Therefore, panel date analysis is used to test the hypothesis. This is the econometric model has been developed to test the hypothesis.

$$
\begin{aligned}
\operatorname{Risk}_{i, t}= & \beta_{1}+\beta_{2}(B Z)_{i, t}+\beta_{3}(N E D)_{i, t}+\beta 4(W O P)_{i, t}+\beta_{5}(C E O)_{i, t}+\beta_{6}(A C)_{i, t}+\beta_{7}(D I)_{i, t}+\beta_{8}(R O A)_{i, t-l}+\beta_{9}(F Z)_{i, t}+\beta_{10} \\
& (F L)_{i, t}+\varepsilon_{i, t}
\end{aligned}
$$

Where,

BZ is board size, NED for Non-executive directors, WOB is Percentage of women, CEOD is CEO Duality, AC is Audit Committee, ROA for performance, FZ is for firm size and LEV is financial leverage. ${ }_{i}$ stands for the firm and varies from 1 to $\mathrm{n} ;{ }_{\mathrm{t}}$ is the year and varies from 2010 to $2017 ; \beta 1$ is the constant that does not vary over time; $\beta_{1}$ to $\beta_{10}$ are the coefficients in the regression; $\varepsilon_{\mathrm{i}, \mathrm{t}}$ it is the residual variable that varies with time; and natural $\log$ board size will be used. As per Green (2003) panel data analysis is the appropriate data analysis technique for a study of secondary data nature as it consists both cross-sectional and time-series data. Therefore, panel date analysis is used to test the hypothesis.

\section{Results}

\subsection{Descriptive Statistics}

Table 1 shows descriptive statistics of the study. Total Risk (TR) is 1.42 with the maximum value of 9.31 and minimum value of 0.34 . The average TR shows 1.42 which is more than 1 implies that Sri Lankan companies experience higher level of total risk. The mean value of the ARR is 1.80 with the maximum value of 43.97 and minimum value of 0.00. Standard deviation has recorded 3.23 meanwhile average shows 1.80 which is more than one as a result TR is validated through ARR hence, both mean depicted the same trend. Financial risk (FR) represents the accounting data. The mean value of the FR is 1.16 with the maximum value of 20 and minimum value of 0.00. Standard deviation has recorded 1.72. The average 1.16 shows that Sri Lankan companies are recorded the risk which is more than one. FR is calculated purely from the accounting data whereas TR calculated from the market data meanwhile ARR calculated with two folder coverage market and accounting data. From the summary descriptive statistics, it confirms that listed companies in Sri Lanka show TR, ARR and TR are positive at the same time mean value more than one. The average board size of listed companies in Sri Lanka is 8.12. The minimum size of board reported is 2 and maximum 15. This is closer to the recommendations of the codes best practice for ideal board size between 5 and 15 members. The standard deviation of board size is 2.12. It proves that the board of listed companies in Sri Lanka had optimum board size as per the mean value.

The average percentage of NED in Sri Lankan board shows 0.36 which is the good sign for the forwardness towards good corporate governance character and compliance with the code of best practices. However, standard deviation shows 13 percentage with the maximum of 81 percentage minimum of 0 percentage. The fraction of women on boards shows that there is variation in the participation of women on boards among the companies. The average representation of women is 0.08 which shows very low proportion and variation between minimum 0.000 and maximum 66\% which shows even many corporate companies do not have the gender balance in Sri Lanka at the same time standard deviation depicted 0.12. 
Table 1. Descriptive statistics: Companies listed in Colombo Stock Exchange in Sri Lanka

\begin{tabular}{lcclcc}
\hline Variables & Mean & Median & Maximum & Minimum & $\begin{array}{c}\text { Standard } \\
\text { Deviation }\end{array}$ \\
\hline Dependent Variables & & & & & \\
Total risk & 1.42 & 1.23 & 9.31 & 0.34 & 0.68 \\
Asset return risk & 1.80 & 0.87 & 43.9 & 0.00 & 3.23 \\
Financial Risk & 1.16 & 0.68 & 20.0 & 0.00 & 1.72 \\
Independent Variables & & & & & \\
Board Size (Nos) & 8.12 & 8.00 & 15.00 & 2.00 & 2.13 \\
Non-executive directors (\%) & 0.36 & 0.33 & 0.81 & 0.00 & 0.13 \\
Women on Boards (\%) & 0.08 & 0.00 & 0.66 & 0.00 & 0.12 \\
CEO Duality & 0.95 & 1.00 & 1.00 & 0.00 & 0.20 \\
Audit Committee & 1.14 & 1.00 & 3.00 & 0.00 & 0.40 \\
Director interlock (\%) & 0.64 & 0.67 & 1.00 & 0.00 & 0.26 \\
Control Variables & & & & & \\
& & & & & \\
ROA (\%) & 0.05 & 0.04 & 0.72 & -0.61 & 0.09 \\
Firm size (Ln) & 21.98 & 22.0 & 26.34 & 12.07 & 1.66 \\
Leverage (Ratio) & 0.19 & 0.14 & 1.62 & 0.00 & 0.18 \\
\hline
\end{tabular}

The results of the statistics show 95 percentage of the listed companies deployed the position of CEO and chairman in Sri Lanka, on the other hand, still around 5 percentage of the companies hold the duality of the position. This result represents that most of the Sri Lankan companies comply with the code of best practices which jointly issued by CASL and SEC in 2013. Audit committee represents the risk monitoring and controlling apex body in the board. The mean shows 1.14 on average in Sri Lankan companies have more than minimum requirement. On the other hand, maximum reported 3.0 minimum 0 which reflect companies still are not compliance with the minimum listing rule of SEC. Director Interlock shows the multi directorship of the directors in other boards. On average, 64 percentage of the Sri Lankan corporates directors are interlocked with other boards. Maximum reported 100 percentage minimum reported 0 percentage and standard deviation shows 26 percentage.

Firm performance is measured by ROA which is directly connected with firm risk at the same time performance determins the risk-taking behaviour. Summary statistics show mean of ROA is 5 percentage and the range of ROA between maximum and minimum 72 percentage, (61.07 percentage) respectively. The negative ROA depicted the loss of the companies. Standard deviation reported 9.05 percentage. Firm size is measured by natural logarithm of total assets. The average firm size reported 21.98 and maximum 26.34, minimum 12.07. The standard deviation of $\log$ of total assets is 1.66. The mean leverage of listed companies is 19 percentage at the same time maximum leverage reported 162 percentage and minimum 0.00 percentage. Maximum leverage shows few companies having the debt capital more than the total asset due to huge net loss. At the same, time some companies are with 100 percentage equity capital.

\subsection{Correlation Analysis}

Table 2 presents Spearman's correlation for all the variables in the research. It shows that the overall correlation results between the dependent and independent variables were low, and not significantly correlated. Note that the data does not indicate multicollinearity problems, which is considered a serious problem if the correlation coefficient between independent variables is above 0.8 (Gujarati, 1995) 
Table 2. Correlation between the variables

\begin{tabular}{|c|c|c|c|c|c|c|c|c|c|c|c|c|}
\hline & TR & ARR & FR & BS & NED & WOB & CEOD & AC & IO & ROA & FZ & LEV \\
\hline TR & 1 & & & & & & & & & & & \\
\hline ARR & 0.472 & 1 & & & & & & & & & & \\
\hline FR & 0.122 & 0.863 & 1 & & & & & & & & & \\
\hline BS & -0.090 & -0.129 & -0.124 & 1 & & & & & & & & \\
\hline NED & -0.084 & -0.061 & -0.027 & 0.011 & 1 & & & & & & & \\
\hline WOB & 0.114 & 0.081 & 0.022 & 0.033 & -0.019 & 1 & & & & & & \\
\hline CEOD & 0.063 & -0.029 & -0.086 & 0.041 & -0.035 & 0.043 & 1 & & & & & \\
\hline $\mathrm{AC}$ & -0.083 & -0.111 & -0.122 & 0.260 & 0.085 & 0.083 & -0.100 & 1 & & & & \\
\hline IO & -0.008 & -0.047 & -0.052 & -0.045 & -0.044 & -0.028 & 0.037 & -0.157 & 1 & & & \\
\hline ROA & -0.028 & 0.175 & 0.295 & -0.078 & 0.001 & -0.024 & -0.011 & -0.053 & -0.04 & 1 & & \\
\hline FZ & -0.337 & -0.302 & -0.200 & 0.298 & 0.070 & -0.163 & 0.075 & 0.241 & 0.106 & -0.004 & 1 & \\
\hline LEV & -0.134 & -0.178 & -0.161 & 0.102 & 0.056 & 0.021 & -0.055 & 0.094 & -0.075 & -0.303 & 0.192 & 1 \\
\hline
\end{tabular}

The results show the relationship between corporate governance variables with risk of the firm. Board size is the foremost character in board structure. Board size is negatively correlated with TR, ARR and FR which depicted weak correlation. NED also negatively correlated with risk measures and reported the weak correlation but at the same time NED positively correlated with board size. The correlation between women on board with TR, ARR, and FR are positive with weak correlation. CEO duality positively related with TR but at the same time negatively correlated with ARR and FR. The correlation between audit committee independence and TR, ARR, and FR are in negative relation, at the same time interlock directorship positively correlated with TR but, negatively correlated with ARR and FR which shows weak relation.

\subsection{Results of Panel Regression}

The Table 3 depicts the results of estimation model 01, model 02 and model 03 . The pre-sign specifies the forecast as made in the propositions. Results revealed that the overall models are significant at $95 \%$ confidence interval level. $\mathrm{R}$-squared value of of all models around 62 percent shows the amount of variation in the dependent variable is explained by the independent variables in the models.

The model 01 results show negative relationship between the board size and firm TR. It means that larger board are associated with low firm TR, on the other hand, smaller board are associated with higher firm TR. However, the relationship was not significant with the coefficient -0.00 , hence, the p-value is higher than the 5 percent significant level $(\mathrm{p}=0.26>0.05)$. In model 02 results show negative relationship between the board size and firm ARR however, the relationship was marginally significant with coefficient -0.12 . At the same time, model 03 results reported negative association with board size and FR with significant relation $-0.10(\mathrm{p}=0.00<0.05)$. Results show that board size is inversely associated with all measures of risk which demonstrate that if board size is small higher risk whereas, if board size is large then lower risk. This finding is consistent with past studies (Cheng, 2008; Pathan,2009; Sudha et al., 2016). According to the results reported that NED proportion is inversely related to all measures of risk which mean higher NED proportion lead to lower the firm risk and lower NED proportion lead to higher the firm risk. 
Table 3. Estimation results of determinants of firm risk and board characteristics

\begin{tabular}{|c|c|c|c|c|c|c|c|}
\hline \multirow[t]{2}{*}{ Explanatory Variables } & \multirow[t]{2}{*}{ Pre-sign } & \multicolumn{2}{|c|}{ Total Risk } & \multicolumn{2}{|c|}{ Asset Return Risk } & \multicolumn{2}{|c|}{ Financial Risk } \\
\hline & & Coefficient & t. statistics & Coefficient & t. statistics & Coefficient & t. statistics \\
\hline $\mathrm{C}$ & & 4.54 & 5.83 & 24.95 & 8.08 & 13.71 & 8.29 \\
\hline Board size & - & -0.00 & -0.15 & $-0.12 *$ & -1.71 & $-0.10 * * *$ & -2.71 \\
\hline Non-executive director & - & -0.18 & -0.89 & $-1.50^{*}$ & -1.87 & $-0.87 * * *$ & -2.02 \\
\hline Women on board & - & $-0.84 * *$ & -1.97 & 1.74 & 1.03 & -0.57 & -0.63 \\
\hline CEO Duality & + & -0.01 & -0.04 & -0.96 & -1.01 & $-0.94 * *$ & -1.84 \\
\hline Audit committee & - & 0.03 & 0.10 & -0.07 & -0.06 & -0.14 & -0.23 \\
\hline Director Interlock & - & 0.02 & 0.17 & $-0.84 *$ & -1.78 & $-0.57 * * *$ & -2.29 \\
\hline ROA & - & 0.26 & 0.99 & $3.37 * * *$ & 3.22 & $2.16^{* * *}$ & 3.85 \\
\hline Firm size & - & $-0.13 * * *$ & -4.26 & $-0.92 * * *$ & -7.17 & $-0.45^{* * *}$ & -6.53 \\
\hline Leverage & - & $0.30 * *$ & 2.00 & 0.39 & 0.66 & -0.22 & -0.69 \\
\hline R-squared & & 0.46 & & 0.62 & & 0.61 & \\
\hline Adjusted R-squared & & 0.38 & & 0.56 & & 0.56 & \\
\hline Hausman test Chi-Squar & statistic & 22.11 & & 16.55 & & 35.41 & \\
\hline Hausman test p-value & & 0.00 & & 0.00 & & 0.00 & \\
\hline F-statistic & & 5.66 & & 11.00 & & 10.77 & \\
\hline Prob (F-statistic) & & 0.00 & & 0.00 & & 0.00 & \\
\hline No of firms & & 156 & & 156 & & 156 & \\
\hline No of observation & & 1248 & & 1248 & & 1248 & \\
\hline
\end{tabular}

Note: This table displays the results from the estimation of the econometric model using generalized least squarefixed effects method. The model fit is also presented; along with the coefficient the t-statistic is reported in parentheses; the superscripts of $*, * *$ and $* * * *$ statistical significance to $10 \%, 5 \%$ and $1 \%$ respectively.

The results of this study are consistent with the theoretical expectation that majority of NEDs on board is inversely related with firm risk in listed company in Sri Lanka. Past risk related literate shows mix results in terms of NED and risk. This is consistent and it could be supported with Sudha et al. (2016) which exhibits the UK sample inversely related but is not significant. But, In Sri Lankan context, the association is inversely significantly related which is consistent with agency theory. In Sri Lankan context, the theory goes together with the finding. The findings based on the practices of listed companies in Sri Lanka were inconsistent with the findings and the practices of previous research and the other countries such as Pathan, (2009) which was positive association and justification that the part time NEDs do not have sufficient related data to mount a challenge to the executive directors in decisions derived at board level.

The risk measures TR and FR negatively associated with women on board with 5\% significant level. It could be concluded that the women on board in Sri Lankan listed companies have an impact on firm risk. It means higher proportion of women lower the firm risk of listed companies in Sri Lanka. This empirical finding is also consistent with the UK finding Sudha et al. (2016) exhibits the UK sample inversely related but is not significant results. At the same time inconsistence of Van der Walt et al. (2006), they did not discovery support for the opinion that gender diversity may have a substantial impact on corporate decision quality. On the other hand, our finding is also consistent with Wilson and Altanlar (2009), Adams and Funk (2011), and Berger et al (2012) show the German sample that women on board positively associated with firm risk. This study exhibits that existing practice in women participation to be considered in order to control the board in order to enhance the firm performance while mitigating the appropriate risk level.

The estimate results for CEO duality is negative and significant, however the theories support for positive association. The results are consistent with the literature. For instance, Pathan (2009) concludes with US sample that duality CEOs to be associated to fewer firm risk and Parrino et al. (2005) displays the powerful CEO desires to take less risky plan. On the other hand, some of the literature show the Powerful CEO prefer to have higher risk, for example 
Adams et al., (2005); Lewellyn \& Muller, (2012) show for the US sample and Sudha et al., (2016) conclude with UK sample that CEO duality positively significantly associated.

Audit committee results show that there is no any significant association with risk measures however, it shows negative coefficient. It means that audit committee independent does not have any impact on firm risk in Sri Lanka. This is inconsistent with agency theory recommendation. In the meantime, this finding goes against the results of Chan and Li (2008) and Aggarwal et al. (2009) show that firms with a high number of independent audit committee members show an increase in the level of financial performance. Erickson et al. (2005) reports a positive relationship between audit committee independence and firm performance. On the other hand, this result is consistent with the study of Mak and Kusnadi (2005) which did not find any significant association between audit committee independence and firm risk. As agency theory suggests to have the independent audit committees to maximize the shareholder wealth while accommodating risk. CSE listing rule mandate the professional involvement in audit committee, however, in Sri Lankan context risk independent professional audit committee does not associate with firm risk TR, positively related to director interlock but the association is not significant with the coefficient. ARR and FR with director interlock show inverse significant relationship. The results depicted that director interlock significantly inversely related with risk of the firms. There is a statistical evidence available to support that there is a negative association between director interlock and firm risk in Sri Lanka. This could be supported with the views by Fligstein and Brantley (1992), Richardson (1987) and Lincoln et al. (1996) report a inverse relation between director interlock and risk of the firm. Therefore, the result of this study is consistent of the theoretical view. At the same time the finding was contrary of the finding of Carrington (1981), Meeusen and Cuyvers (1985) and Keister (1998), Burt (1983) reports positive association. So, it could be concluded that in-corporate governance variable director interlocking has a significant relation between directors inter locking and risk of the firm listed companies in Sri Lanka.

\subsection{Robustness Test}

For stationary specification of data, unit root test was deployed to confirm the stationary of the data. Based on the results, it could be determined that all the variables are significant at 5 percent. Therefore, as per the Levin, Lin \& $\mathrm{Chu}$ (LLC) $\mathrm{t}$ Statistics and probability all these variables are stationary. To test the multi-collinearity issues the VIF is used. The cut-off value of VIF is 10 and for tolerance value is 0.10 . This shows that there are no multi-collinearity problems with the independent variables Therefore, this non-violation of assumption depicts that each independent variable act independently in models.

\subsubsection{Testing Endogenous Variables Using Instrumental Variables Estimation}

Instrumental variable estimation method is used to estimate the empirical model by finding independent instruments which replace the dependent variables. Then the independent instruments are regressed on the dependent variables to find unbiased results. From past research, board size and proportion of NEDs are the known independent variables; therefore, these variables are instrumented (Pathan, 2009). Instrumental variable estimation eliminates simultaneity bias, if there is any. Existing literature by Linck et al. (2008) developed the variables that explain board size and NEDs on the board, which are adapted for this study and are shown below.

Equation (C) is similar to equation (1) estimated earlier in the study, except that in this estimation, board size and NEDs have been estimated using equations (A) and (B). The equations (A)-(C) are estimated using the GLS estimation method and the equations are shown below Table 4.

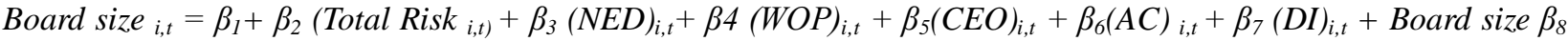

$$
\begin{aligned}
& (R O A)_{i, t-1}+\beta_{9}(F Z)_{i, t}+\beta_{10}(F L)_{i, t}+\varepsilon_{i, t} \\
& N E D_{i, t}=\beta_{1}+\beta_{2}\left(B Z_{i, t)}+\beta_{3}(\text { Total Risk })_{i, t}+\beta 4(W O P)_{i, t}+\beta_{5}(C E O)_{i, t}+\beta_{6}(A C)_{i, t}+\beta_{7}(D I)_{i, t}+\beta_{8}(R O A)_{i, t-1}+\beta_{9}(F Z)_{i, t}\right. \\
& +\beta_{10}(F L)_{i, t}+\varepsilon_{i, t}
\end{aligned}
$$


Table 4. Estimation results from equation 01, 02 and 03

\begin{tabular}{lcccccc}
\hline Explanatory Variables & \multicolumn{2}{c}{ Board Size (A) } & \multicolumn{2}{c}{ NED (B) } & \multicolumn{2}{c}{ Total Risk (C) } \\
\cline { 2 - 7 } & Coefficient & t. statistics & Coefficient & t. statistics & Coefficient & t. statistics \\
\hline Board size & - & - & $-0.09^{*}$ & -1.69 & -0.00 & -1.14 \\
Total Risk & -0.14 & -0.11 & -0.82 & -0.72 & - & - \\
Non-executive director & $-0.17^{* *}$ & -0.09 & - & - & -0.07 & -0.78 \\
Women on board & -0.74 & -0.85 & $0.63 * *$ & 0.74 & $-0.77^{* *}$ & -1.85 \\
CEO Duality & -0.03 & -0.02 & -0.23 & -1.00 & -0.0 & -0.02 \\
Audit committee & 0.03 & 0.12 & 0.04 & 0.04 & 0.02 & 0.08 \\
Director Interlock & 0.19 & 0.02 & 0.56 & 0.47 & 0.01 & 1.04 \\
ROA & 0.25 & 0.74 & $2.58^{* *}$ & 2.47 & 0.19 & 3.85 \\
Firm size & $-0.12^{* * *}$ & -4.11 & $-0.92^{* * *}$ & -7.17 & $-0.12 * * *$ & -3.45 \\
Leverage & $0.28^{* *}$ & 1.96 & 0.28 & 0.52 & $0.21 * * *$ & 1.88 \\
R-squared & & & 0.54 & & 0.47 & 0.36 \\
Adjusted R-squared & 0.40 & & 0.46 & & 1248 & \\
No of observation & 1248 & & 1248 & & & \\
\hline
\end{tabular}

Note: This table displays the results from the estimation of the econometric model using generalized least squarefixed effects method. The model fit is also presented; along with the coefficient the t-statistic is reported in parentheses; the superscripts of $*, * *$ and $* * * *$ statistical significance to $10 \%, 5 \%$ and $1 \%$ respectively.

On examining the determinants of board size in Table 4 [equation (A)], it is found that the size of the board is significantly associated with the proportion of NEDs on the board, and firm size. Equation (B) shows that the percentage of NEDs on the board depends on board size, the women on board, audit committee, director interlock, firm size, firm risk, firm performance and leverage. With regards to causality, the estimation shows that firm risk is not significantly associated with the variables of board size and the proportion of NEDs. The results of the estimation for equation $(\mathrm{C})$ show that total firm risk is determined by three significant factors, namely, women on board, firm size and leverage. The results are qualitatively similar to the estimation done in the main model. This confirms that after controlling for endogeneity, women on board is associated with firm risk.

\section{Conclusion}

This study investigates how board features such as board size, board independence, chairman/CEO duality, women proportion in the board, director interlocking and audit committee independence influence on firm's risk. This is very important due to the fact that emerging economies have practical issues while implementing the corporate governance system. To attain the investigation aims, a quantitative research method was implemented and secondary data were obtained from the annual reports of 156 listed companies listed on the Colombo Stock Exchange for the period 2010 to 2017. Listed companies in Sri Lanka are compliance with Code of best practices by the way of average board size are around 8 members, around 36 percentage of the members are NED in the board, 95 percentage of the boards are separated the duality of the position and audit committee included mean more than one professional independent NED in the board which are mandatory of the code of best practices. Apart from that, gender balance was analyzed even though it was not mentioned in the code shows 8 percentage of the board filled by women which depicted more insight of the board, multi directorship shows the mean of 64 percentage interlocked with other firms. The results give more understanding about the influence of board structure characteristics on risk of the firm.

The number of risk measures is used to examine the influence of board characteristics on risk. The finding shows that under board attribute variables such as Board size, Women on board, non-executive director, CEO Duality and Director Interlock seems to be significant impact on firm risk. These finding are consistent with agency theory perspective. In addition to that, these results validated the theoretical stand. Further, Sri Lankan companies' boards characteristics validated the agency theory assumption and recommendation. This is an important exploration according to the theoretical perspective. On the other hand, Audit committee does not show any impact on firm risk. This particular finding of the empirical study reveals that inconsistence with theoretical expectation and code best 
practices, because, theory and code of best practices recommended that audit committee is the committee for the controlling and monitoring of the firm's risk and return whereas, this result shows contradictive results. This knowledge is very important for the practitioners and regulators to take meaningful measures in appointing audit committee.

On the other angle, this study uses multiple risk measures for the robustness of the measures. Risk measures were selected with multiple perspectives. Total risk was calculated entirely from the maker data whereas, asset return risk was calculated using market and financial data but financial risk was calculated entirely form company financial data. Out for three measures the financial risk was the mostly influencing risk measure. The main implication of this finding for the regulators, investors, policy makers and government is to use board structure variables as internal risk control mechanism and the same time potential investors can consider these variables to assess the firm risk. Further, the finding of this study is useful for companies listed in Sri Lanka to implement the risk assessment tool and threshold level of board character. When the code of best practices amendment take place, the policy makers can consider women proportion and interlock directorship for the enhancement of the performance and maximize the shareholders wealth.

The limitation of this study is that it covered a few board attributes variables of the corporate boards. Due to time and data constraint some other variables were not covered such as age of the director, tenure of the directors and directors' remuneration. The results of the study would have been different, if variables had extended. This study is conducted on companies listed in CSE in Sri Lanka, so that, it cannot be generalized to private companies. Future, researchers will be able to address the in-depth inside of firm risk if the variables include age of the director, tenure of the directors and directors' remuneration. These variables also directly influence risk taking behaviour of the firms. The present study only considers the Sri Lankan companies perspective but in future comparative study could undertake with another emerging economy on this theme.

\section{References}

Adams, R., \& Ferreira, D. (2010). Moderation in groups: Evidence from betting on ice break-ups in Alaska. Review of Economic Studies,77, 882-913. https://doi.org/10.1111/j.1467-937X.2009.00594.x

Adams, R., Almeida, H., \& Ferreira, D. (2005). Powerful CEO's and their impact on corporate performance. The Review of Financial Studies, 18(4). https://doi.org/10.1093/rfs/hhi030

Adams, R., Almeida, H., \& Ferreira, D. (2005). Powerful CEOs and their impact on corporate performance. Review of Financial Studies, 18, 1403-1432. https://doi.org/10.1093/rfs/hhi030

Aggarwal, R., Erel, I., Stulz, R., \& Williamson, R. (2009). Differences in governance practices between US and foreign firms: measurement, causes, and consequences. The Review of Financial Studies, 22(8), 3131-3169. https://doi.org/10.1093/rfs/hhn107

Amihud, Y., \& Lev, B. (1981). Risk reduction as a managerial motive for conglomerate mergers. Bell Journal of Economics, 12, 605-617. https://doi.org/10.2307/3003575

Barber, B., \& Odean, T. (2001). Boys will be boys: gender, overconfidence, and common stock investment. Quarterly Journal of Economics, 116, 261-292. https://doi.org/10.1162/003355301556400

Baxter, P., \& Cotter, J. (2009). Audit committees and earnings quality. Accounting \& Finance, 49(2), 267-290. https://doi.org/10.1111/j.1467-629X.2008.00290.x

Benkraiem, R., Hamrouni, M, Lakhal, F., \& Toumi, N. (2017). Board independence, gender diversity and CEO compensation. Corporate Governance: The International Journal of Business in Society, 7(5), 845-860. https://doi.org/10.1108/CG-02-2017-0027

Beasley, M. (1996). An empirical analysis of the relation between the board of director composition and financial statement fraud. Accounting Review, 1(4), 443-465.

Berger, A., Kick, T., \& Schaeck, K. (2012). Executive board composition and bank risk-taking. Deutsche Bundes bank: Disscusion Paper. https://doi.org/10.2139/ssrn.2007021

Byrd, J., \& Hickman, K. (1992). Do outside directors monitor managers? Evidence from tender offer bids. Journal of Financial Economics, 32, 195-221. https://doi.org/10.1016/0304-405X(92)90018-S

Cadbury. (1992). Report on the Committee on the Financial Aspects of Corporate Governance. London: Gee, London.

Cannon, T. (1994). Corporate Responsibility. A Textbook on Business Ethics, Governance, Environment: Roles and 
Responsibilities. London: Pitman.

Carpenter, M., Pollock, T., \& Leary, M. (2003). Testing a model of reasoned risk-taking: Governance, the experience of principals and agents, and global strategy in high-technology IPO firms. Strategic Management Journal, 24, 803-820. https://doi.org/10.1002/smj.338

Carrington, P. (1981). Horizontal co-optation through corporate interlocks. PhD dissertation. Toronto: University of Toronto.

Chaganti, R., Mahajan, V., \& Sharma, S. (1985). Corporate board size, composition and corporate failures in retailing industry. Journal of Management $\quad$ Studies, $22, \quad 400-416$. https://doi.org/10.1111/j.1467-6486.1985.tb00005.x

Chan, K., \& Li, J. (2008). Audit committee and firm value: Evidence on outside top executives as expert independent directors. Corporate Governance: An International Review, 16(1), $16-31$. https://doi.org/10.1111/j.1467-8683.2008.00662.x

Cheng, S. (2008). Board size and the variability of corporate performance. Journal of Financial Economic, 87, 157-176. https://doi.org/10.1016/j.jfineco.2006.10.006

Christy, J., Matolcsy, Z., Wright, A., \& Wyatt, A. (2013). Do board characteristics influence the shareholders' assessment of risk for small and large firms?. Journal of Accounting, Finance and Business Studies, 49, 2. https://doi.org/10.1111/abac.12005

COSO. (2009). Effective Enterprise Risk oversight: The role of the board of directors. Committee of Sponsoring Organization.

Croson, R., \& Gneezy, U. (2009). Gender differences in preferences. Journal of Economic, 1-27. https://doi.org/10.1257/jel.47.2.448

Crouhy, M., Galai, D., \& Mark, R. (2014). The Essentioals of Risk Managment (2nd ed.). New York: Mc Graw Hill Education.

Dalton, D., Daily, C., Ellstrand, A., \& Johnson, J. (1998). Meta-analytic reviews of board composition, leadership structure, and financial performance. Strategic management journal, 19(3), 269-290. https://doi.org/10.1002/(SICI)1097-0266(199803)19:3<269::AID-SMJ950>3.0.CO;2-K

Davis, J., Schoorman, F., \& Donaldson, L. (1997). Towards a Stewardship Theory of Management. Academy of Management Review, 22, 20-47. https://doi.org/10.5465/amr.1997.9707180258

Devos, E., Prevost, A., \& Puthenpurackal.J. (2009). Are Interlocked Directors Effective Monitors?. Financial Management, Winter, 861-887. https://doi.org/10.1111/j.1755-053X.2009.01059.x

Eling, M., \& Marek, S. (2011). Corporate governance and risk taking: Evidence from the U.K. and German insurance markets. Institute of Insurance Economics. Working Papers on Risk Management and Insurance, 103.

Erickson, J., Park, Y. W., Eising, J., \& Shin. (2005). Board composition and firm value under concentrated ownership: the Canadian evidence. Pacific-Basin Finance Journal, 13(4), 387-410. https://doi.org/10.1016/j.pacfin.2004.11.002

Fama, E. (1980). Agency problems and the theory of the firm. The Journal of Political Economy, 88(2), $288-307$. https://doi.org/10.1086/260866

Fama, E., \& Jensen, M. (1983). Separation of ownership and control. Journal of Law and Economics, 26, $327-349$. https://doi.org/10.1086/467038

Farwis, M., \& Azeez, A. (2019). Corporate Ownership Structure and Firm Risk: Empirical Evidence from Listed Companies in Sri Lanka. Journal of Finance and Bank Management, 7(2), $72-81$. https://doi.org/10.15640/jfbm.v7n2a5

Farwis, M., \& Nazar, M. (2019). Interlocking Directorate and Firm Performance of Listed Companies in Sri Lanka. Asian Journal of Research in Banking and Finance, 9(3), 1-15. https://doi.org/10.5958/2249-7323.2019.00003.8

Felo, A., Krishnamurthy, S., \& Solieri, S. (2003). Audit committee characteristics and the perceived quality of financial reporting: an empirical analysis. https://doi.org/10.2139/ssrn.401240

Ferri, M., \& Jones, W. (1979). Determinants of financial structure: a new methodological approach. Journal of 
Finance, 34, 631-644. https://doi.org/10.1111/j.1540-6261.1979.tb02130.x

Finch, E., \& Shivdasani, A. (2006). Are Busy Boards Effective Monitors?. Journal of Finance, 19(2), 689-724. https://doi.org/10.1111/j.1540-6261.2006.00852.x

Flannery, M., \& Rangan, K. (2008). What caused the bank capital build-up of the 1990s. Review of Finance, 12(2), 391-429. https://doi.org/10.1093/rof/rfm007

Fligstein, N., \& Brantley, P. (1992). Bank control, owner control, or organizational dynamics:who controls the large modern corporation?. American Journal of Sociology, 98(2), 280-307. https://doi.org/10.1086/230009

Goel, A., \& Thakor, A. (2008). Overconfidence, CEO selection, and corporate governance. Journal of Finance, 63, 2737-2784. https://doi.org/10.1111/j.1540-6261.2008.01412.x

Goodstein, J., \& Boeker, W. (1991). Turbulence at the top: a new perspective on governance structure changes and strategic change. Academy of Management Journal, (34), 306-330. https://doi.org/10.2307/256444

Hambrick, D., \& Finkelstein, S. (1987). Managerial discretion: a bridge between polar views of organizational outcomes. Research in Organizational Behaviour, 9, 369-406.

Green, W. H. (2003). Econometric Analysis. Upper Saddle River: Prentice Hall.

Gujarati, D. (2003). Basic econometrics (4 ed.). New York: McGraw Hill Publishing.

Harrison, J. (1987). The strategic use of corporate board committees. California Management Review,30(1), 109. https://doi.org/10.2307/41165269

Hunton, J., \& Rose, J. (2008). Can directors' self-interests influence accounting choices?. Accounting, Organizations and Society, 33, 783-800. https://doi.org/10.1016/j.aos.2007.10.001

Huse, M., \& Solberg, A. (2006). Gender-related boardroom dynamics: how Scandinavian women make and can make contributions on corporate boards. Women in Management Review, 21(2), 113-130. https://doi.org/10.1108/09649420610650693

Hutchinson, M. (2001). Firm risk, corporate governance and firm performance. Governance and corporate social responsibility in the new millennium: Governance and Social Responsibility Conference: proceedings of the 2001 Conference (pp. 1-16). Burwood, Vic.: School of Accounting and Finance,Deakin University.

Izraeli, D. (2000). Women on Corporate Boards of Directors: International Challenges and Opportunities. Women Directors in Israel, 75-96. https://doi.org/10.1007/978-90-481-3401-4_6

Jaggi, B., Leung, S., \& Gul, F. (2009). Family control, board independence and earnings management: evidence based on Hong Kong firms. Journal of Accounting and Public Policy, 28(4), 281-300. https://doi.org/10.1016/j.jaccpubpol.2009.06.002

Jamal, \& Bhuiyan. (2015). Interlocking Directorship in New Zealand. Australasian Accounting, Business and Finance Journal, 9(3), 45-58. https://doi.org/10.14453/aabfj.v9i3.4

Jensen, M. (1993). The modern industrial revolution, exit, and the failure of internal control systems. The Journal of Finance, 48(3), 831-880. https://doi.org/10.1111/j.1540-6261.1993.tb04022.x

Jensen, M., \& Meckling, W. (1976). Theory of the firm: Managerial behaviour, agency costs and ownership structure. Journal of Financial Economics, 3(4), 305-360. https://doi.org/10.1016/0304-405X(76)90026-X

Jewell, L., \& Reitz, H. (1981). Group Effectiveness in Organizations. Scott-Foresman, Glenview, IL.

Jianakoplos, A. N., \& Bernasek, A. (1998). Are women more risk averse?. Economic Inquiry, 36, 620-630. https://doi.org/10.1111/j.1465-7295.1998.tb01740.x

Keister, L. (1998). Engineering growth: business group structure and firm performance in China's transition economy. American Journal of Sociology, 104(2), 404-440. https://doi.org/10.1086/210043

Keys, P., \& Li. (2005). Evidence on the market for professional directors. The Journal of Financial Research, 28, 575-589. https://doi.org/10.1111/j.1475-6803.2005.00140.x

Klein, A. (2002a). Audit committee, board of director characteristics, and earnings management. Journal of Accounting and Economics, 33, 375-400. https://doi.org/10.1016/S0165-4101(02)00059-9

Kogan, N., \& Wallach, M. (1964). Risk taking: A study in cognition and personality. New York: Holt.

Kosnik, R. (1990). Reviewed effects of board demography and directors' incentives on corporate greenmail 
decisions. The Academy of Management Journal, 33, 129-150. https://doi.org/10.2307/256355

Laeven, L., \& Levine, R. (2009). Bank governance, regulation and risk-taking. Journal of Financial Economics, 93(2), 259-275. https://doi.org/10.1016/j.jfineco.2008.09.003

Lewellyn, K., \& Muller-Kahle, M. (2012). CEO power and risk-taking: evidence from the subprime lending industry. Corporate Governance: An International Review, 20(3), 289-307. https://doi.org/10.1111/j.1467-8683.2011.00903.x

Lincoln, J., Gerlach, M., \& Ahmadjian, C. (1996). Keiretsu networks and corporate performance in Japan. American Sociological Review, 61(1), 67-88. https://doi.org/10.2307/2096407

Lipton, M. (1992). A modest proposal for improved corporate governance. Business Lawyer, 48(1), 48-59.

Maddala, G. (1986). Limited-dependent and qualitative variables in econometrics. Cambridge United Kingdom: Cambridge University Press.

Manconi, A. M., \& Yasuda, A. (2012). The role of institutional investors in propagating the crisis of 2007-2008. Journal of Financial Economics, 104(3), 491-518. https://doi.org/10.1016/j.jfineco.2011.05.011

Mapitiya, G. S., Ajward, A. R., \& Seneratne, S. (2015). Ownership Concentration and Degree of Compliance with Corporate Governance Best Practices of Public Listed Companies in Sri Lanka. NSBM Journal of Management, l(1).

Marra, A., Mazzola, P., \& Prencipe, A. (2011). Board monitoring and earnings management pre-and post-IFRS. The International Journal of Accounting, 46(2), 205-230. https://doi.org/10.1016/j.intacc.2011.04.007

McNulty, T., \& Pettigrew, A. (1999). Strategists on the board. Organization Studies, 20(1), 47-74. https://doi.org/10.1177/0170840699201003

Meeusen, W., \& Cuyvers, L. (1985). The interaction between interlocking directorships and the economic behavior of companies in Stockman. In R. Ziegler, \& J. Scott (Eds.), Networks of Corporate Power (pp. 45-72). Polity: Cambridge.

Mizruchi, M. (1996). What do interlocks do? An analysis, critique, and assessment of research on interlocking directorates. Annual Review of Sociology, 22, 271-298. https://doi.org/10.1146/annurev.soc.22.1.271

Mizruchi, M., \& Galaskiewicz, J. (1994). Networks of interorganizational relations. In J. Wasserman, \& J. Galaskiewicz (Eds.), Advances in Social Network Analysis (pp. 230-253). CA: Sage,Thousand Oaks. https://doi.org/10.4135/9781452243528.n9

Moscovici, S., \& Zavalloni, M. (1969). The group as a polarizer of attitudes. Journal of Personality and Social Psychology, 12, 125-135. https://doi.org/10.1037/h0027568

Munro, L., \& Buckby, S. (2008). Audit committee regulation in Australia: How far have we come? Australian Accounting Review,18(4), 310-323. https://doi.org/10.1111/j.1835-2561.2008.0020.x

Nazar, M. (2016). Does CEO duality affect the firm performance? Evidence from Sri Lanka. International Journal of Advances in Management and Economics, 5(2), 56-60.

Nguyen, P. (2011). Corporate governance and risk-taking: Evidence from Japanese firms. Pacific-Basin Finance Journal, 19, 278-297. https://doi.org/10.1016/j.pacfin.2010.12.002

Niederle, M., \& Vesterlund, L. (2007). Do women shy away from competition? Do men compete too much?. Quarterly Journal of Economics, 122, 1067-1101. https://doi.org/10.1162/qjec.122.3.1067

O'Reilly, C., Caldwell, D., \& Barnett, W. (1989). Work group demography, social integration, and turnover. Administrative Science Quarterly, 34, 21-37. https://doi.org/10.2307/2392984

Parrino, R., Poteshman, A., \& Weisbach, M. (2005). Measuring investment distortions when risk-averse managers decide whether to undertake risky projects. Financial Management, 34(1), 21-60. https://doi.org/10.1111/j.1755-053X.2005.tb00091.x

Pathan, S. (2009). Strong boards, CEO power and bank risk-taking. Journal of Banking and Finance, 33(7), 1346-1350. https://doi.org/10.1016/j.jbankfin.2009.02.001

Pennings, J. (1980). Interlocking Directorates. San Francisco.: Jossey Bass.

Pfeffer, J. (1972). Size and Composition of Corporate Board of Directors: The Organization and its Environment. Administrative Science Quarterly, 17, 218-239. 
Powell, M., \& Ansic, D. (1997). Gender differences in risk behaviour in financial decision-making: an experimental analysis. Journal of Economic Psychology, 18, 605-628. https://doi.org/10.1016/S0167-4870(97)00026-3

Rajeevan, S., \& Ajward, R. (2019). Board characteristics and earnings management in Sri Lanka. Journal of Asian Business and Economic Studies. https://doi.org/10.1108/JABES-03-2019-0027

Report, D. (2011). Women on boards. Retrieved from www.bis.gov.uk/assets/biscore/business-law/docs/w/11-745-women-on-boards.pdf

Richardson, R. (1987). Director interlocks and corporate profitability. Administrative Science Quarterly, 32(3), 367-386. https://doi.org/10.2307/2392910

Saat, N., Karbhari, Y., Xiao, J., \& Heravi, S. (2012). Factors affecting independent audit committee members' effectiveness - the case of listed firms on Bursa Malaysia. World Review of Business Research, 2(3), 132-147.

Sah, R., \& Stiglitz, J. (1986). The architecture of economic systems: hierarchies and ployarchies. American Economic Review, 76, 716-727.

Sanders, W., \& Hambrick, D. (2007). Swinging for the fences: The effects of CEO stock options on company risk taking and performance. Academy of Management Journal, 50, 1055-1078. https://doi.org/10.5465/amj.2007.27156438

Senaratne, S., \& Gunaratne, P. (2008). Corporate governance development in Sri Lanka: prospects and problem. Journal of Management.

Senaratne, S., \& Gunaratne, P. (2009). Corporate governance of Sri Lankan listed companies: Significant features and issues. Colombo review, Journal UOC, 1(1).

Sorensen, D. P., \& Miller, S. E. (2017). Financial accounting scandals and the reform of corporate governance in the United States and in Italy. Corporate Governance: The International Journal of Business in Society, 17(1), 77-88. https://doi.org/10.1108/CG-05-2016-0125

Stiles, P., \& Taylor, B. (2002). Boards at Work-How Directors View their Roles and Responsibilities. Oxford: Oxford University Press. https://doi.org/10.1093/acprof:oso/9780199258161.001.0001

Subramaniam, N., McManus, L., \& Zhang, J. (2009). Corporate governance, firm characteristics and risk management committee formation in Australian companies. Managerial Auditing Journal, 24(4), 316-339. https://doi.org/10.1108/02686900910948170

Sudha, M., Ibrahim, S., \& Archbold, S. (2016). Boards attributes that increase firm risk - evidence from the UK. Corporate Governance, 16(2), 233-258. https://doi.org/10.1108/CG-09-2015-0122

Wilson, N., \& Altanlar, A. (2009). Director Characteristics, gender balance and insolvency risk: an empirical study. https://doi.org/10.2139/ssrn.1932107

Wiseman, R., \& Gomez-Mejia, L. (1996). A behavioral agency model of managerial risk taking. Academy of Management Review,23, 133-153. https://doi.org/10.5465/amr.1998.192967

Wright, P., Ferris, S., Sarin, A., \& Awasthi, V. (1996). Impact of corporate insider, blockholder, and institutional equity ownership on firm risk-taking. Academy of Management Journal, 39, 441-463. https://doi.org/10.2307/256787

Yermack, D. (1996). Higher market valuation of companies with a small board of directors. Journal of Financial Economics, 40(2), 185-211. https://doi.org/10.1016/0304-405X(95)00844-5

\section{Copyrights}

Copyright for this article is retained by the author(s), with first publication rights granted to the journal.

This is an open-access article distributed under the terms and conditions of the Creative Commons Attribution license (http://creativecommons.org/licenses/by/4.0/). 